\title{
Sirih Merah (Piper crocatum Ruiz \& Pav.) Kajian Pustaka Aspek Botani, Kandungan Kimia, dan Aktivitas Farmakologi
}

\author{
Nani Parfati dan Tri Windono \\ Fakultas Farmasi Universitas Surabaya, Surabaya \\ Korespondensi: Nani Parfati \\ Email: nani_parfati@staff.ubaya.ac.id
}

\begin{abstract}
ABSTRAK: Sirih merah (Piper crocatum Ruiz \& Pav.) banyak dimanfaatkan masyarakat untuk pengobatan, antara lain: hipertensi, radang liver radang prostat, radang mata, keputihan, maag, kanker payudara, nyeri sendi, penurun dan pengontrol kadar gula darah, serta untuk kosmetika. Berdasarkan hal tersebut telah banyak dilakukan pengujian praklinik untuk melakukan kajian kandungan kimia, serta aktivitas farmakologi dari tanaman ini. Kajian pustaka menunjukkan bahwa Sirih merah merupakan salah satu jenis Piper yang tersebar di beberapa wilayah di dunia, termasuk Indonesia. Tanaman ini mengandung minyak atsiri (monoterpen, seskuiterpen), alkaloid, flavonoid (golongan auron), tanin-polifenol, steroid, dan senyawa neolignan, sedangkan pengujian farmakologi menunjukkan bahwa tanaman ini mempunyai aktivitas antiinflamasi, antimikroba, antifungi, antihiperglikemik, antiproliferasi, dan antioksidan.
\end{abstract}

Kata kunci: Sirih merah; Piper crocatum Ruiz \& Pav.; botani; kandungan kimia; aktivitas farmakologi

\begin{abstract}
Ornamental Piper (Piper crocatum Ruiz \& Pav.) have been used by people in Indonesia as medicine of hypertension, hepatic, prostatic and eye inflammations, fluor albus, gastritis, breast cancer, arthritis, hypoglicaemic agent as well as cosmetic. According those situation many preclinical researchs for chemical compounds test and pharmacological activity test of this plant have been done. Literature studies have shown that ornamental piper is a member of Piper can be found worldwide, including in Indonesia. This plant contains essential oils (monoterpenes, sesquiterpenes), alkaloids, flavonoids (aurons), tanins-polyphenols, steroids, and neolignans compound. Pharmacological activity tests have shown that ornamental piper have antiinflammation, antimicrobe, antifungi, antihyperglicaemic, antiproliferation and antioxidant.
\end{abstract}

Keywords: Ornamental piper; Piper crocatum Ruiz \& Pav.; botanic; chemical compounds; pharmacologic activity 


\section{Pendahuluan}

Tanaman sirih-sirihan (Piper, suku: Piperaceae) banyak dimanfaatkan masyarakat sebagai tanaman hias, sayuran, rempah-rempah, ramuan obat, maupun sebagai perlengkapan (uborampe) dalam upacara-upacara adat. Di dunia terdapat sekitar 700 jenis Piper [1], 1000 jenis [2], bahkan menurut Jones dan Luchsinger [3], terdapat antara 1400 - 2000 jenis Piper dari berbagai negara. Di Pulau Jawa, terdapat sekitar 23 jenis Piper [4]. Piper tumbuh di ketinggian 0 - $2500 \mathrm{~m}$, dan hanya beberapa jenis yang tumbuh di ketinggian di atas $3000 \mathrm{~m}$ [5]. Di Indonesia, sirih-sirihan merupakan tanaman yang populer untuk obat, antara lain: lada/merica (Piper nigrum L.) sebagai antimikroba, antihipertensi, antiasma, antiinflamasi, hepatoprotektif dan antioksidan [6], sirih (Piper betle L.) sebagai antidiabetes, inhibisi platelet, imunomodulator, antioksidan, dan antikanker [7], cabe Jawa (Piper longum L.) sebagai analgesik, antioksidan, antiinflamasi, imunomodulator, antidiabetes, dan antiasma [8], dan kemukus (Piper cubeba L.f.) sebagai antioksidan [9]. Akhirakhir ini diperkenalkan suatu jenis Piper yang oleh masyarakat dimanfaatkan selain sebagai tanaman hias, juga sebagai ramuan obat Nusantara, yaitu sirih merah (Piper crocatum Ruiz \& Pav., Gambar 1). Klasifikasi tanaman ini adalah sebagai berikut [3]:

Divisi: Magnoliophyta

Kelas: Magnoliopsida

Anak kelas: Magnoliidae

Bangsa: Piperales

Suku: Piperaceae (sirih-sirihan)

Marga: Piper

Jenis: Piper crocatum Ruiz \& Pav.

Sinonim: Steffensia crocata Kunth; Artanthe crocata Miq. [10].

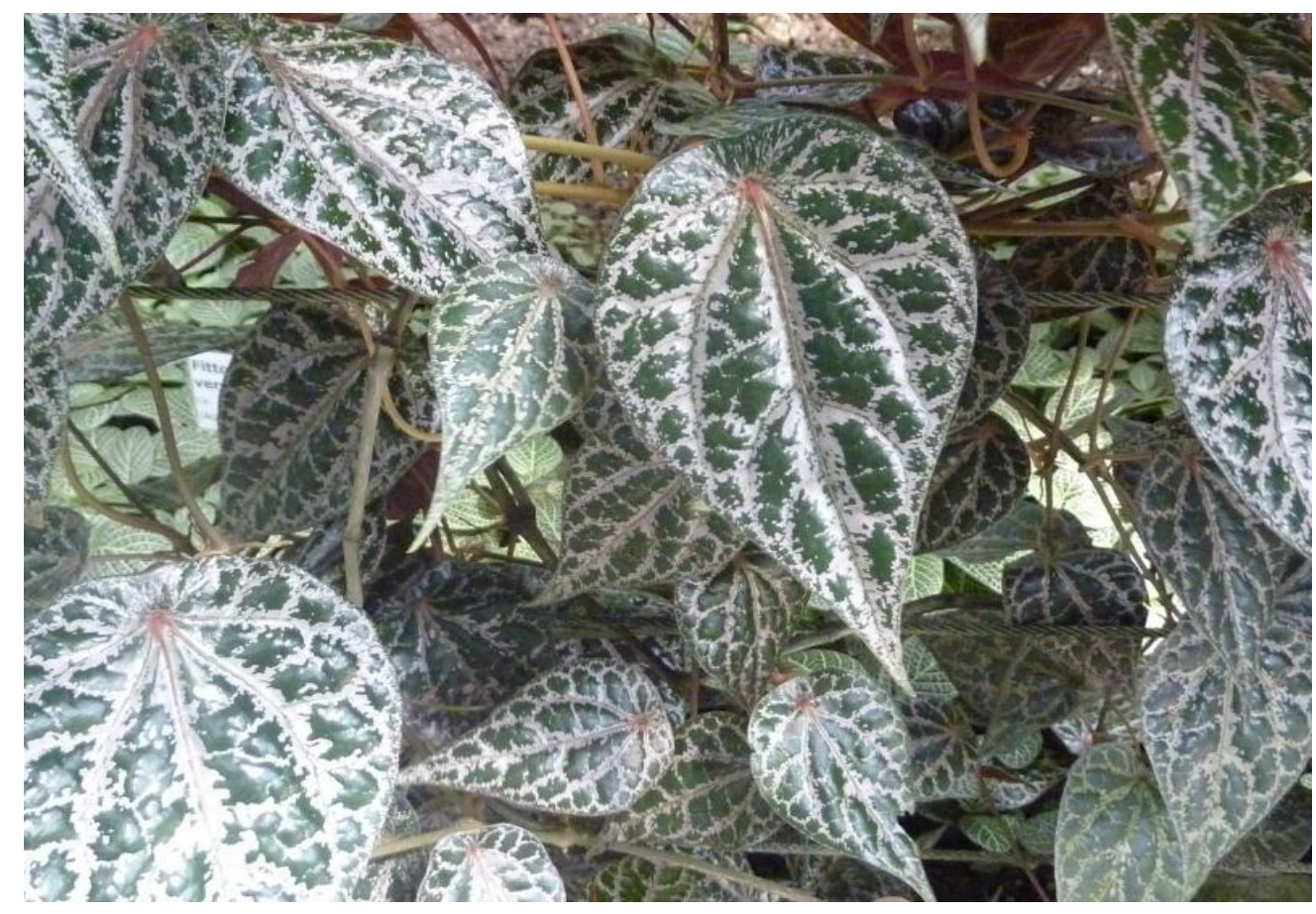

Gambar 1. Tanaman Sirih merah (Piper crocatum Ruiz \& Pav.) 
Sirih merah merupakan tanaman asli Peru [10], kemudian menyebar ke beberapa wilayah di dunia, termasuk Indonesia. Sirih merah merupakan tanaman semak, batang bersulur dan beruas, dengan jarak buku antara 5-10 cm, dan pada setiap buku tumbuh bakal akar. Daun bertangkai, berbentuk ellips, acuminatus, sub acut pada basalnya dengan bagian atas meruncing, tepi rata, mengkilap atau tidak berbulu. Panjangnya 9-12 cm dan lebarnya 4-5 cm. Urat daun pinnatus dari separuh bagian bawah, urat daunnya 4-5 x 2, bullulatus-lacunosa. Petiolus, panjang 10 $\mathrm{mm}$, spike panjang 90-110 mm, tebal $5 \mathrm{~mm}$ [10]. Daun bagian atas berwarna hijau tua, dengan daerah sekitar tulang daun keperakan, dan bagian bawah berwarna ungu. Daun berlendir, berasa pahit dengan bau kurang spesifik.

Dalam pengobatan tradisional, sirih merah banyak dimanfaatkan untuk pengobatan hipertensi, radang liver, radang prostat, radang mata, keputihan, maag, kanker payudara, nyeri sendi, penurun dan pengontrol kadar gula darah, kosmetika, obat gangguan jantung, TBC tulang, keputihan akut, tumor payudara, antiseptik untuk mengeliminasi mikroorganisme dari kulit atau luka, misal disebabkan oleh Candida albicans. Sebagai obat kumur dapat membantu mencegah pembentukan plak gigi dan radang gusi, obat batuk ekspektoran.

\section{Kandungan kimia}

Hasil skrining kandungan kimia menunjukkan bahwa daun sirih merah mengandung senyawa golongan flavonoid, alkaloid, tanin-polifenol [11$13]$, steroid-terpenoid, dan saponin $[12,13]$.

\subsection{Senyawa flavonoid}

Pembuktian lebih lanjut terhadap jenis flavonoid yang terdapat dalam daun sirih merah: Daniel [14] telah berhasil mengisolasi suatu senyawa flavonoid dari fraksi etil asetat ekstrak metanol daun, dengan karakteristik: $\mathrm{Rf}=0,24$ (hek- san-etil asetat 20-80); 0,30 (etil asetat) dan 0,35 (metanol). Titik leleh $150-156^{\circ} \mathrm{C}$. UV-Vis (metanol): 269 dan $418 \mathrm{~nm}$. IR: 3070,68 $\mathrm{cm}^{-1}$ (ulur $\mathrm{CH}$ Sp2); 2924,09 dan $2854,65 \mathrm{~cm}^{-1}$ (ulur CH alifatik); 1728,22 $\mathrm{cm}^{-1}$ (gugus karbonil); 1604,77 $\mathrm{cm}^{-1}$ ( $\mathrm{C}=\mathrm{C}$ aromatik); $1265,30 \mathrm{~cm}^{-1}$ (C-0); 1118,71 $\mathrm{cm}^{-1}$ (C-O-C). Berdasarkan data karakteristik yang diperoleh disimpulkan bahwa senyawa flavonoid tersebut adalah golongan auron. Sirih merah juga mengandung senyawa flavonol dan kuersetin [12].

Sebagai bahan perbandingan dapat dikemukakan bahwa: dari estrak air daun Piper sarmentosum dapat diisolasi senyawa flavonoid rutin (glikosida flavonol) dan vitexin (C-glikosida flavon) [15]. Fraksi etil asetat ekstrak metanol daun P. solmsianum C. DC. var. solmsianum mengandung senyawa flavonoid orientin (C-glikosida flavon) [16]. Dua senyawa flavonoid, masing-masing: [(S)-8-formyl-3',5-dihydroxy-7-methoxy-6-methylflavanone (senyawa flavanon) dan 3 '-formyl3,4',6'-trihydroxy-2'-metoksi-5'-methylchalcone (senyawa kalkon) dapat diisolasi dari ekstrak etanol ranting kering P. montealegreanum Yuncker [17]. Fraksi etil asetat ekstrak bebas lemak daun $P$. aduncum Linn, mengandung senyawa kalkon, 2,6-dihydroxy-4-methoxy-dihydrochalcone [18]. Berdasarkan hasil-hasil penelitian tersebut, dapat disimpulkan bahwa senyawa flavonoid dalam marga Piper meliputi hampir semua golongan flavonoid.

\subsection{Minyak atsiri}

Senyawa terpenoid yang terdeteksi dalam skrining fitokimia, sangat mungkin berasal dari minyak atsiri yang merupakan senyawa yang umum dijumpai pada marga Piper. Batubara et al. [19] berhasil memisahkan minyak atsiri dari daun Sirih merah asal Bogor (metode destilasi uap) dengan rendemen 0,21\% w/w. Hasil analisis Kromatografi Gas-Spektrometri Massa, dengan kolom DB-5 MS, gas pembawa helium terdeteksi adanya senyawa-senyawa monoterpen ( $\alpha$-thujene, $\alpha$-pinene, sabinene, $\beta$-myrcene, 
$\alpha$-terpinene, $\beta$-phellandrene, $\gamma$-terpinene, $\beta$-terpineol, terpinolen, $\alpha$-terpineol, copaene), seskuiterpen (caryophyllene, $\alpha$-caryophyllene dan germacrene D). Menurut Batubara et al. [19], komponen minyak atsiri sirih merah hampir sama dengan sirih (Piper betle L.), bedanya pada sirih ditemukan adanya senyawa monoterpen (champene), dan senyawa fenil propanoid (chavicol dan eugenol) yang tidak terdeteksi dalam sirih merah (Tabel 1).

Sebagai bahan perbandingan yang lain, bahwa minyak atsiri daun marga Piper asal Brazilia [1] mempunyai kandungan sebagai berikut: P. amalago dengan komponen utama (persentase $>5 \%$ ) $\alpha$-pinene, camphene, limonene, dan borneol); $P$. dilatatum (cis-beta ocimene, $\beta$-caryophyllene, germacrene D, bicyclogermacrene, spathulenol, dan caryophyllene oxide); P. ovatum ( $\alpha$-pinene, $\beta$-pinene, $\beta$-caryophyllene, germacrene $\mathrm{D}$, dan epicubebol); P. arboreum (bicyclogermacrene, spathulenol, caryophyllene oxide dan dua senyawa yang tidak teridentifikasi); $P$. hispidum ( $\alpha$-pinene, $\beta$ pinene, $\delta$-3-carene, spathulenol, $\alpha$-cadinol); Piper xylosteoides (myrcene, $\alpha$-terpinene, $p$-cymene, dan $\gamma$-terpinene); P. tectonifolium ( $\alpha$-pinene, $\beta$ pinene, dan caryophyllene oxide).

\subsection{Alkaloid}

Hasil skrining fitokimia menunjukkan bahwa sirih merah mengandung senyawa alkaloid, tetapi belum diketahui jenisnya [12, 13]. Dalam marga Piper, lazim terdapat kandungan alkaloid, sebagai contoh: piperine (alkaloid inti piperidin) terisolasi dan teridentifikasi dalam P. nigrum L. [20-22], P. longum [22, 23], dan P. retrofractum Vahl. [24]. Selain itu, dijumpai pula adanya senyawa alkaloid lain dalam Piper, yaitu Cenocladamide (Dihidropiridone alkaloid) dari daun P. cenocladum [25].

\subsection{Senyawa lignan dan neolignan}

Dari daun sirih merah diisolasi adanya senyawa neolignan, 1-allyl-3,5-dimethoxy-7-methyloxo-6-(3,4,5-trimethoxyphenyl) bicyclo $[3,2,1]$ oct-2-en-8-yl acetate (Gambar 2) [12].

Dari marga Piper telah diisolasi senyawa-senyawa lignan dan neolignan. Diantara senyawa lignan adalah: cubebin, diisolasi dari buah Piper cubeba [26, 27], dan dari daun P. cernuum [28], hinokinin dan yatekin [27]. Beberapa senyawa neolignan yang telah diisolasi dari marga Piper, antara lain: piperkadsin $\mathrm{C}$ dan fotoquinol dari $P$. kadsura [29]; eupomatenoid-5, eupomatenoid-6 dan conocarpan dari P. regnelii (MIQ) C.DC. var.

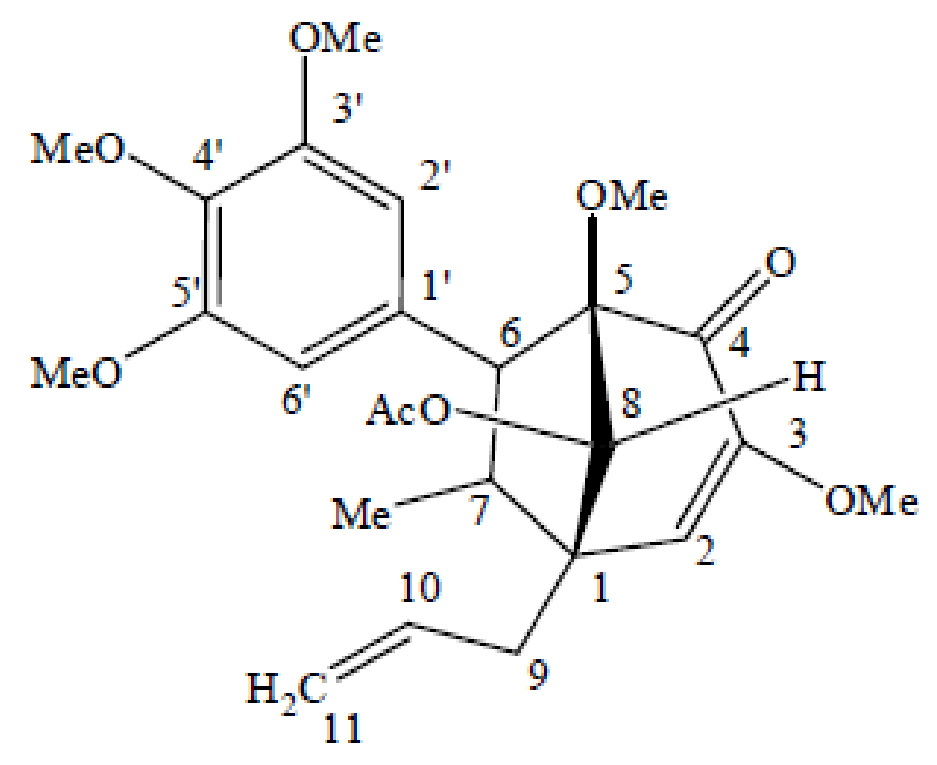

Gambar 2. 1-allyl-3,5-dimethoxy-7-methyl-oxo-6-(3,4,5-trimethoxyphenyl) bicyclo [3,2,1] oct-2-en-8yl acetate 


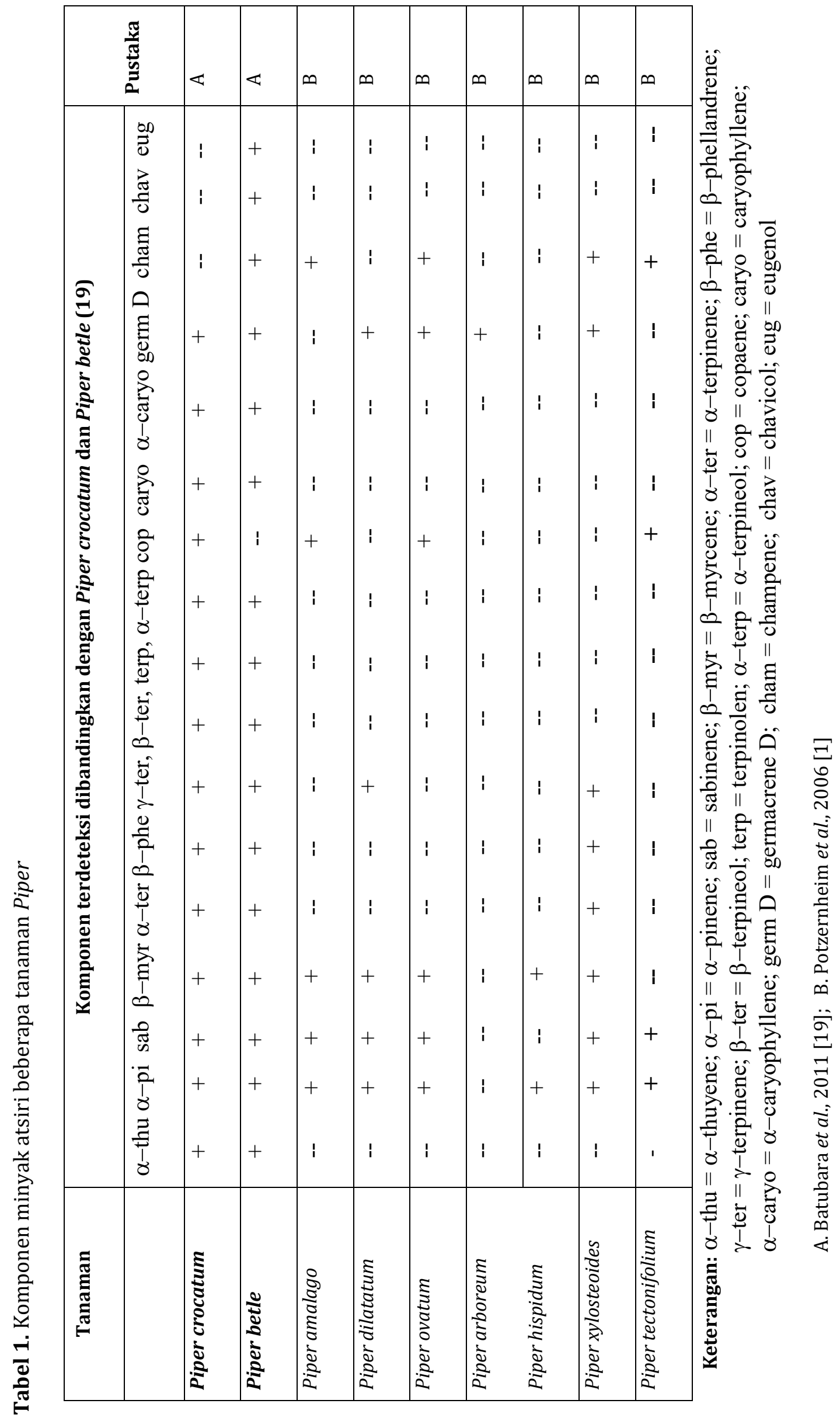


pallescens (C. DC.) Yunck [30] dan andamanicin dari P. sumatranum var. andamanica [31].

\section{Aktivitas farmakologi}

Beberapa pustaka melaporkan bahwa sirih merah mempunyai berbagai aktivitas farmakologi, antara lain: antiinflamasi, antimikroba, antijamur, antihiperglikemik, antiproliferasi, dan antioksidan.

\subsection{Antiinflamasi}

Fitriyani et al. [13], dengan metode induksi karagenin pada kaki tikus telah melakukan percobaan, menggunakan tiga dosis ekstrak metanol kering daun sirih merah, masing-masing 25 , 50 dan $100 \mathrm{mg} / \mathrm{kgBB}$ dan pembanding suspensi asetosal 1\%. Hasil percobaan menunjukkan bahwa ekstrak dengan dosis $50 \mathrm{mg} / \mathrm{kgBB}$ mempunyai aktifitas antiinflamasi (berdasarkan daya reduksi bengkak) terbesar (85,60\%), lebih besar dibanding dosis $25 \mathrm{mg} / \mathrm{kgBB}$ (72,3\%); dosis 100 $\mathrm{mg} / \mathrm{kgBB}(81,02 \%)$ dan suspensi asetosal 1\% (77,58\%). Terdapat perbedaan yang bermakna aktifitas antiinflamasi antara ekstrak dosis 25 dan $50 \mathrm{mg} / \mathrm{kgBB}$ dengan asetosal 1\%, tetapi tidak terdapat perbedaan yang bermakna antara ekstrak dosis $100 \mathrm{mg} / \mathrm{kgBB}$ dengan asetosal 1\%.

Beberapa jenis Piper juga menunjukkan aktivitas antiinflamasi, seperti yang dilaporkan oleh Vagashiya et al. [32] terhadap ekstrak etanol daun Piper sarmentosum, P. argyrophyllum, P. longum, P. betle dan $P$. chaba. Komponen aktif antiinflamasi yang pernah dilaporkan dari ekstrak Piper antara lain: dillapiole dan dihydrodillapiole (komponen minyak atsiri) dari P. aduncum [33]; piperovatine dan piperlonguminine (senyawa amida) dari $P$. ovatum Vahl. [34, 35].

\subsection{Antimikroba dan antifungi}

Ekstrak etanol daun sirih merah terbukti mempunyai efek anti bakteri terhadap Staphylococcus aureus ATCC 25923 dan Escherichia coli ATCC 35218, masing-masing pada Konsentrasi
Hambat Minimal (KHM) dan Konsentrasi Bunuh Minimal (KBM) 25\% untuk S. aureus dan 6\% untuk E. coli [36]. Mutmainnah et al. [37] membuktikan bahwa ekstrak daun Sirih merah 12,5\% dapat memperbaiki gambaran histopatologi luka insisi kulit tikus putih yang terinfeksi $S$. aureus. Kesimpulan tersebut diperoleh berdasarkan data jumlah neutrofil, makrofag, fibroblas, angiogenesis serta kepadatan kolagen.

Rizky et al. [38] melaporkan bahwa ekstrak etanol daun Sirih merah pada kepekatan $40 \% \mathrm{v} / \mathrm{v}$ memiliki daya hambat terhadap pertumbuhan fungi Candida albicans ATCC 10231 paling efektif dibanding dengan kepekatan yang lain, dengan lebar daya hambat tertinggi (13,3 mm). Ekstrak etanol daun sirih merah pada kepekatan $40 \% \mathrm{v} / \mathrm{v}$ menunjukkan daya hambat lebih tinggi dibanding ekstrak 10\%, 20\%, 80\% maupun 100\% v/v. Tetapi, penelitian Dhewayani et al. [39] menunjukkan bahwa ekstrak air (infusa) daun sirih merah dengan kepekatan 1,875 sampai 30\% tidak mampu menghambat pertumbuhan C. albicans. Menurut Oktaviani [40], ekstrak daun sirih merah 100\% memiliki efektifitas yang baik dalam menghambat pertumbuhan fungi Pityrosporum ovale pada penderita ketombe, dengan kekuatan daya anti fungi sebanding dengan Zinc Pyrithion 1\%.

Minyak atsiri dari daun dan buah P. aduncum (komponen tertinggi: linalool) menunjukkan aktivitas antifungi terhadap C. sphaerospermum. Minyak atsiri buah P. tuberculatum (komponen tertinggi senyawa monoterpen: $\beta$-pinene, $\alpha$-pinene dan senyawa seskuiterpen: $\beta$-caryophyllene) menunjukkan aktivitas antifungi terhadap C. cladospoiroides, sedangkan minyak atsiri batangnya (komponen tertinggi $\beta$-caryophyllene, $\alpha$-pinene dan $\beta$-pinene) menghambat fungi $C$. sphaerospermum. Semua minyak atsiri menunjukkan KHM $10 \mu \mathrm{g} / \mathrm{ml}$ [41].

De Campos et al. [16] melaporkan bahwa ekstrak metanol dan fraksi heksan, diklorometan serta etil asetat ekstrak metanol daun Piper solmsianum DC. C. var. solmsianum mampu menghambat pertumbuhan 12 jenis fungi dermatofit patogenik, dengan KHM antara 20-60 $\mu \mathrm{g} / \mathrm{ml}$. Tetapi, 


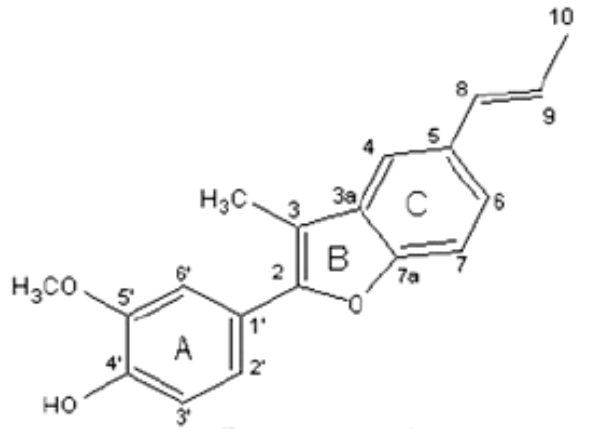

(a)

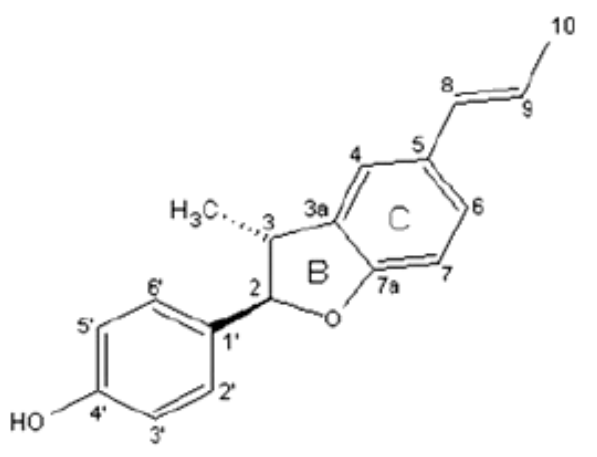

(b)

Gambar 3. Struktur kimia eupomatenoid-5 (a) dan conocarpan (b) [16]

semuanya tidak mampu menghambat pertumbuhan hyaline hypho-mycetes dan hanya sedikit aktif terhadap zigomycetes dan ragi. Isolat dari tumbuhan ini yaitu, senyawa neolignan: eupomatenoid-5 dan conocarpan (Gambar 3), serta senyawa flavonoid, orientin mampu menghambat 12 jenis fungi dermatophytes (KHM antara 1-9 $\mu \mathrm{g} / \mathrm{ml}$ ) dengan potensi yang setara dengan ketoconazole. Conocarpan juga mampu menghambat pertumbuhan ragi. Kesimpulan yang ditarik adalah: senyawa aktif antifungi dari P. solmsianum adalah senyawa neolignan: eupomatenoid-5 dan conocarpan, serta senyawa flavonoid orientin.

Hydroxychavicol (HC) yang diisolasi dari fraksi kloroform ekstrak air daun $P$. betle L. menunjukkan daya antifungi terhadap berbagai ragi (KHM: 1562 - $500 \mu \mathrm{g} / \mathrm{ml}$ ), berbagai jenis Aspergillus (KHM: $125-500 \mu \mathrm{g} / \mathrm{ml}$ ), berbagai Dermatophytes (KHM: 7,81-62,5 $\mathrm{g} / \mathrm{ml}$ ) sedangkan Konsentrasi Fungisida Minimum (KFM) kira-kira sama atau dua kali lebih besar dari KHM. HC menunjukkan extended post antifungal effect dari 6,25 menjadi 8,70 jam pada konsentrasi 4 kali KHM terhadap jenis - jenis Candida, dan menekan timbulnya mutan-mutan dari jenis-jenis fungi yang diuji pada konsentrasi 2 sampai 8 kali KHM. HC juga menghambat pembentukan biofilm yang disebabkan oleh C. albicans dan mengurangi preformed biofilm-biofilmnya. Karena terjadi peningkatan pemakaian propidium iodida oleh sel-sel C. albicans apabila diberi perlakuan dengan $\mathrm{HC}$, maka diduga mekanisme kerja antifungi HC terhadap
C.albicans adalah dengan mengganggu membran C. Albicans [42].

Minyak atsiri daun Sirih merah menunjukkan daya antifungi yang lemah terhadap Streptococcus mutans (KHM > 0,6\%), tetapi mempunyai daya menghambat pembentukan biofilm serta daya degradasi biofilm yang cukup tinggi, masing-masing dengan $\mathrm{IC}_{50}=0,012 \%$, dan $\mathrm{EC}_{50}=$ $0,017 \%$ [43].

\subsection{Antihiperglikemik}

Dekokta daun sirih merah segar dengan takaran 3,22 dan $20 \mathrm{~g} / \mathrm{kgBB}$ perhari selama 10 hari, masing-masing mampu menurunkan kadar glukosa darah (pengukuran menggunakan glukometer elektronik) tikus Sprague Dawley diabetik aloksan (takaran $150 \mathrm{mg} / \mathrm{kgBB}$, ip), sebesar 23,61 dan 37,41\%. Pengurangan ini sama seperti pemberian Daonil (takaran 3,22 mg/kgBB per hari selama 10 hari). Pada pemberian dekok dengan takaran seperti di atas terjadi penurunan berat badan tikus sebesar, masing-masing 17,05 dan 5,43\%. Hasil penelitian menyimpulkan bahwa dekok daun Sirih merah segar bersifat antihiperglikemik dan khususnya pada takaran 3,22 $\mathrm{mg} / \mathrm{kgBB}$ mampu menurunkan berat badan tikus diabetik aloksan [11].

\subsection{Antiproliferasi}

Wicaksono et al. [44] membuktikan bahwa ekstrak metanol daun $P$. crocatum Ruiz \& Pav. mampu menghambat pertumbuhan sel kanker payudara manusia (T47D) in-vitro, melalui me- 
kanisme penghambatan fosforilasi p44/p42. Tidak teramati adanya sel apoptosis. Sel T47D ditumbuhkan dan dipelihara dalam medium DMEM, dengan tambahan beberapa suplemen. Parameter uji yang digunakan meliputi viabilitas sel (metode MTT), morfologi sel dan inti (metode DAPI), serta penentuan bagian sub-G1 setelah penambahan ekstrak (Flow cytometric analysis). Di samping itu juga dilakukan pendeteksian perubahan kadar mitogen p44 dan p42 yang diaktivasi oleh enzim protein tyrosine kinase (Immunoblotting method). Signaling p44/p42 dipelajari karena jalur signaling ini telah dikaitkan dengan pertumbuhan sel serta menggambarkan target penting untuk terapi kanker.

\subsection{Antioksidan}

Dengan menggunakan metode DPPH (1,1-diphenyl-2-picrylhydrazyl), Rachmawati dan Ciptati [12] membuktikan bahwa ekstrak n-heksana, etil asetat dan etanol daun Sirih merah bersifat antioksidan, masing-masing dengan harga $\mathrm{IC}_{50}$ sebesar 94,63; 127,74 dan 134,29 ppm, sedangkan vitamin $\mathrm{C}$ pembanding menunjukkan harga $\mathrm{IC}_{50}$ sebesar 3,61 ppm. Di samping itu fraksi yang mengandung alkaloid mempunyai harga $\mathrm{IC}_{50}$ sebesar 50,91 ppm, sedangkan isolat neolignan daun sirih merah tidak aktif sebagai antioksidan. Ekstrak metanol buah P. nigrum dan P. cubeba menunjukkan efek antioksidan dengan metode DPPH, masing-masing dengan $\mathrm{IC}_{50}$ sebesar 144,1 dan 11,3 ppm, sedangkan vitamin $C$ menunjukkan IC ${ }_{50}$ sebesar 8,9 ppm [45].

\subsection{Tyrosinase inhibitor}

Tyrosinase adalah enzim yang dapat mensintesis tyrosin. Enzim ini dapat mengoksidasi fenol-fenol menjadi melanin. Melanin adalah pigmen yang berperan penting dalam mencegah terjadinya kanker kulit dengan melindungi sel-sel permukaan tubuh dari radiasi sinar ultraviolet. Akibat terbentuknya melanin, maka kulit menjadi berwarna gelap. Berdasarkan hal tersebut penghambatan kerja enzim dapat digunakan sebagai, bahan atau senyawa yang mampu menghambat pembentukan melanin, sehingga digunakan sebagai pencerah kulit. Minyak atsiri hasil destilasi uap dari $P$. betle mampu menghambat aktivitas tyrosinase, sedangkan minyak atsiri dari $P$. crocatum tidak. Diperkirakan komponen minyak atsiri yang mampu menghambat aktivitas tyrosinase adalah fenilpropanoid (chavicol dan eugenol) yang terdapat dalam minyak atsiri $P$. betle, tetapi tidak terdapat dalam minyak atsiri $P$. crocatum [19].

\section{Kesimpulan}

Dari hasil penelusuran pustaka dan pembahasan yang telah dilakukan dapat disimpulkan hal-hal sebagai berikut: sirih merah (Piper crocatum Ruiz \& Pav.) merupakan salah satu jenis Piper yang tersebar di beberapa wilayah di dunia, termasuk Indonesia. Tanaman ini telah banyak dimanfaatkan oleh masyarakat Indonesia untuk berbagai macam pengobatan alternatif. Kandungan kimia daun Sirih merah meliputi: senyawa flavonoid: quersetin dan senyawa golongan auron; minyak atsiri dengan komponen monoterpen: $\alpha$-thujene, $\alpha$-pinene, sabinene, $\beta$-myrcene, $\alpha$-terpinene, $\beta$-phellandrene, $\gamma$-terpinene, $\alpha$-terpineol, terpinolen, copaene, seskuiterpen: caryophyllene, $\alpha$-caryophyllene dan germacrene D; senyawa neo-lignan: 1-allyl-3,5-dimethoxy7-methyl-oxo-6-(3,4,5-trimethoxyphenyl) bicyclo [3,2,1]oct-2-en-8-yl acetate; senyawa golongan alkaloid, tanin-polifenol, steroid-terpenoid dan saponin. Penelitian terhadap beberapa aktivitas farmakologi menunjukkan bahwa daun Sirih merah bersifat sebagai antiinflamasi, anti mikroba dan antifungi, antihiperglikemik serta anti-proliferasi.

\section{Daftar pustaka}

1. Potzernheim M, Bizzo HR, Agostini-Costa TS, Viera RF, Carvalho-Cilva M, Gracindo LAMB. Chemical characterization of seven Piper species (Piperace- 
ae) from Federal District, Brazil, based on volatile oil constituents. Rev. Bras. Pl. Med. 2006;8:10-2.

2. Chaveerach A, Mokkamul P, Sudmoon R, Tanee T. Ethnobotany of the genus Piper (Piperaceae) in Thailand. Ethnobotany Research \& Applications. 2006;4:223-31.

3. Jones SB, Luchsinger AE. Plant systematics, 2nd Ed., New York: McGraw-Hill Publishing Co, USA;1986.

4. Backer CA, Bakhuizen RC V.d. Brink. Flora of Java,Vol.1, Groningen: NVP. Noordhoff; 1965.

5. Quijano-Abril MA, Callejas-Posada R, MirandaEsquivel DR. Areas of endemism and distribution patterns for neotropical Piper species (Piperaceae). J. Biogeogr. 2006;33:1266-78.

6. Damanhouri ZA, Ahmad A. A Review on therapeutic potential of Piper nigrum L. (Black Pepper): The king of spices. Medicinal \& Aromatic Plants. 2014;3(3):1-6.

7. Bhalerao SA, et al. Phytochemistry, pharmacological profile and therapeutic uses of Piper betle linn.-an overview. Journal of Pharmacognosy and Phytochemistry. 2013;1(2):10-9.

8. Dhanalakshmi D, Umamaheswari S, Balaji D, Santhanalakshmi R, and Kavimani S. Phytochemistry and pharmacology of Piper longum: A systematic review. World Journal of Pharmacy and Pharmaceutical Sciences. 2017;6(1):381-98.

9. Nahak G, Sahu RK. Phytochemical evaluation and antioxidant activity of Piper cubeba and Piper nigrum. Journal of Applied Pharmaceutical Science. 2011;1(8):153-7.

10. Macbride JF, Dahlgreen BE. Flora of Peru, part II, Chicago: USA, 1936:155.

11. Safithri M, Fahma F. Potency of Piper crocatum decoction as an antihyperglycaemia in rat strain sprague dawley. Journal of Biosciences. 2008;15(1):45-8.

12. Rahmawati IS, Ciptati. Isolasi senyawa antioksidan dari daun sirih merah (Piper crocatum). Prosiding Simposium Nasional Inovasi Pembelajaran dan Sains, Bandung-Indonesia; 2011:327-33.

13. Fitriyani A, Winarti L, Muslichah S, Nuri. Uji antiinflamasi ekstrak metanol daun sirih merah (Piper crocatum Ruiz \& Pav.) pada tikus putih. Majalah
Obat Tradisional. 2011;16(1):34-42.

14. Daniel. Isolasi dan identifikasi senyawa flavonoid pada fraksi etil asetat dari daun tumbuhan sirih merah (Piper crocatum Ruiz \& Pav.). Mulawarman Scientiae. 2010;9(1):17-26.

15. Ugusman A, Zakaria Z, Hui CK, Nordin NA, Mahdy ZA. Flavonoids of Piper sarmentosum and its cytoprotective effects against oxidative stress. EXCLI journal. 2012;11:705-14.

16. De Campos MP, Filho VC, Da Silva RZ, Yunes RA, Zacchino S, Juares S, Bella Cruz RC, Bella Cruz A. Evaluation of antifungal activity of Piper solmsianum C. DC. var. solmsianum (Piperaceae). Biol. Pharm. Bull. 2005;28(8):1527-30.

17. Alves HS, de Souza MFV, Chaves MCO. Three New Compounds from Piper montealegreanum Yuncker (Piperaceae). J. Braz. Chem. Soc. 2011;22(8):1610-5.

18. Ahmad F, Rahmani M. Chemical constituents of Piper aduncum Linn (Piperaceae). Pertanika J. Sci. \& Technol. 1993;1(2):185-8.

19. Batubara I, Rahminiwati M, Darusman LK, Mitsunaga T. Tyrosinase activity of Piper betle and Piper crocatum essential oil. Proceeding of The International Conference on Basic Science. 2011:50-3.

20. Jansz ER, Pathirana IC, Packiyasothy EV. Determination of piperine in pepper (Piper nigrum L.). J. Natn. Sci. Coun. Sri Lanka. 1983;11(1):129-38.

21. Wood AB, Barrow ML, James DJ. Piperine determination in pepper (Piper nigrum L.) and its oleoresin - A reversed-phase high-performance liquid chromatography method. Flav. Fragr. J. 1988;3:55-64.

22. Hamrapurkar PD, Jadhav K, Zine S. Quantitative estimation of piperine in Piper nigrum and Piper longum using high performance thin layer chromatography. Journal of Applied Pharmaceutical Science. 2011;01(03):117-20.

23. Swapna DPR, Junise V, Shibin P, Senthila S, Rajesh RS. Isolation, identification and antimycobacterial evaluation of piperine from Piper longum. Der Pharmacia lettre. 2012;4(3):863-8.

24. Kardono LBS, Artanti N, Dewiyanti ID, Basuki T, Padmawinata K. Selected Indonesian medicinal plants, monographs and desciptions, Vol. I, Jakar- 
ta: Penerbit Grasindo; 2003:393.

25. Dodson CD, Dyer LA, Searcy J, Wright Z, Letourneau DK. Cenocladamine, a dihydropyridone alkaloid from Piper cenocladum. Phytochemistry. 2000;53(1):51-4.

26. Wahyono, Wahyuono S, Mursyidi A, Hakim L, Timmerman H, Verpoorte R. Identifikasi kubebin dan epikubebin hasil isolasi dari buah Piper cubeba L.f dengan spektroskopi RMI dua dimensi. MFI. 2005;16(4):32-8.

27. Elfahmi. Phytochemical and biosynthetic studies of lignans, with a focus on Indonesian medicinal plants. 2006:46-52.

28. Danelutte AP, Costantin MB, Delgado GE, Braz-Filho R, Kato MJ. Divergence of secondary metabolism in cell suspension cultures and differentiated plants of Piper cernuum and P. crassinervum. J. Braz. Chem. Soc. 2005;16(6B):1425-30.

29. Kim KH, Choi JW, Ha SK, Kim SY, Lee KR. Neolignans from Piper kadsura and their antineuroinflammatory activity. Bioorg. Med. Chem. Lett. 2010;20(1):409-12.

30. Luize PS, Ueda-Nakamura T, Dias Filho BP, Cortez DA, Nakamura CV. Activity of neolignans isolated from Piper regnelii (MIQ) C.DC. var. pallescens (C.DC.) Yunck. against Trypanosoma cruzi. Biol. Pharm. Bull. 2006;29(10):2126-30.

31. Malhotra S, Koul SK, Taneja SC, Pushpangadan P, Dhar KL. A neolignan from Piper sumatranum. Phytochemistry. 1990;29(8):2733-4.

32. Vagashiya $Y$, Nair R, Chanda S. Investigation of some piper species for anti-bacterial and anti-inflammatory property. Inter. J. Pharmacol. 2007;3(5):403-5.

33. Parise-Filho $\mathrm{R}$, et al. The anti-inflammatory activity of dillapiole and some semisynthetic analogues. Pharm. Biol. 2011;49(11):1173-9.

34. Rodriguez SD, Baroni S, Svidzinski AE, BersaniAmado CA, Cortez DA. Antiinflammatory activity of extract, fractions and amides from the leaves of Piper ovatum Vahl (piperaceae). J. Ethnopharmacol. 2008;116(3):569-73.

35. Agnihotri S, Wakode S, Agnihotri A. An overview on anti-inflammatory properties and chemo- profiles of plants used in traditional medicine. Indian Journal of Natural Products Resources. 2010;1(2):150-67.

36. Juliantina F, Citra DA, Nirwani B, Nurmasitoh T, Bowo ET. Manfaat sirih merah (Piper crocatum) sebagai agen antibakterial terhadap bakteri gram positif dan gram negatif. JKKI. 2009;1(1):12-20.

37. Mutmainnah A. Pengaruh pemberian ekstrak daun sirih merah (Piper crocatum) terhadap gambaran histopatologi luka insisi kulit tikus putih yang terinfeksi Staphylococcus aureus. Karya ilmiah FKH, Universitas Airlangga, Surabaya; 2013.

38. Rizky OR. Uji daya antifungi ekstrak etanol daun sirih merah (Piper crocatum Ruiz \& Pav.) terhadap Candida albicans ATCC 10231 secara in vitro. Karya ilmiah FK, UMS, Surakarta; 2012.

39. Dhewayani IN. Efektifitas infusa daun sirih merah (Piper crocatum) terhadap pertumbuhan Candida albicans. Karya ilmiah FKG Universitas Airlangga, Surabaya; 2012.

40. Oktaviani D. Uji banding efektivitas ekstrak daun sirih merah (Piper crocatum) dengan zinc pyrithione $1 \%$ terhadap pertumbuhan pityrosporum ovale pada penderita berketombe. Karya ilmiah FK, Universitas Diponegoro, Semarang; 2012.

41. Navickiene HMD, et al. Composition and antifungal activity of essential oils from Piper aduncum, $\mathrm{Pi}$ per arboreum and Piper tuberculatum. Quim.Nova. 2006;29(3):467-70.

42. Ali I, et al. In vitro antifungal activity of hydroxychavicol isolated from Piper betle L. Annals of Clinical Microbiology and Antimicrobials. 2010;9(1):7.

43. Hertiani T, Pratiwi SUT, Irianto IDK, Adityaningrum D, Pranoto B. Effect of Indonesian medicinal plants essential oils on Streptococcus mutans biofilm. MFI. 2011;22(3):174-81.

44. Wicaksono BD, et al. Antiproliferative effect of the methanol extract of Piper crocatum Ruiz \& Pav. leaves on human breast (T47D) cells in-vitro. Trop. J. Pharm. Res. 2009;8(4):345-52.

45. Khalaf NA, Shakya AK, Al-Othman A, El-Agbar Z, Farah H. Antioxidant activity of some common plants. Tur. J. Biol. 2008;32(1):51-5. 